\title{
Métodos efectivos de enseñanza en el pensamiento mediático y el modelo de lección por alfabetización en la búsqueda de soluciones prácticas desde la perspectiva de los docentes
}

\author{
Effective methods of teaching in media thinking and literacy lesson and providing \\ practical solutions form teachers' perspective
}

\author{
Mohammad Pishbaz ${ }^{1}$, Soolmaz Nourabadiª
}

Shahed University, Tehran. Iran ${ }^{12}$

(iD) Orcid ID: https://orcid.org/0000-0002-7308-1353 ${ }^{1}$

Orcid ID: https://orcid.org/0000-0002-9292-80112

Recibido: 15 de enero de 2020

Aceptado: 18 de julio de 2020

\section{Resumen}

La alfabetización mediática es un conjunto de habilidades de aprendizaje referentes a la capacidad de acceder, analizar y crear una variedad de mensajes mediáticos. También la alfabetización mediática es una habilidad esencial en el mundo de hoy. Para avanzar al complejo entorno de medios de hoy, deberíamos poder comprender mejores mensajes de medios. Las personas con conocimientos mediáticos podrán descubrir los mensajes complejos que se encuentran en televisión, radio, periódicos, revistas, libros, vallas publicitarias, Internet y otros medios independientes. También pueden crear sus propios medios y participar activamente en la configuración de la cultura de los medios. En este sentido, el presente estudio ha identificado un nuevo libro sobre "Pensamiento mediático y alfabetización" en las escuelas secundarias, desde la perspectiva de los maestros, desde los aspectos de los métodos de enseñanza, incluidos los contextos, procesos, aportes y resultados. En esta investigación, el tipo de investigación es una aplicada, que se realiza por método descriptivo y encuesta. La población estadística estaba compuesta por todos los maestros del décimo nivel de la escuela en el distrito 18 de Teherán y el tamaño de la muestra se determinó usando la tabla Morgan. Después de una encuesta de docentes, análisis de datos. Los resultados con el uso de One Sample T-Test indicaron que los métodos de enseñanza de este libro fueron de medio a alto, en términos de contextos, entradas, procesos y salidas. Además, los resultados de la prueba de Friedman muestran que la prioridad más importante de los métodos de enseñanza de este libro fueron los factores contextuales, y el factor menos importante son las entradas.

Palabras clave: Plan de estudios, alfabetización mediática, enseñanza, pensamiento, capacitación en alfabetización mediática.

\footnotetext{
Abstract

Media literacy is a set of learnable skills that refers to the ability to access, analyze, and create a variety of media messages. Also, media literacy is an essential skill in today's world. To move into today's complex media environment, we should able to understand better media messages. People with media literacy will be able to discover the complex messages found in television, radio, newspapers, magazines, books, billboards, internet and other independent media. They
} 
can also create their own media and participate actively in shaping media culture. In this regard, the present study has identified a new book on "Media Thinking and Literacy" at secondary high schools, from the teachers' perspective, from the aspects of teaching methods including contexts, process, input and output. In this research, the type of research is an applied one, which is done by descriptive method and survey. The statistical population consisted of all teachers of 10th level of school in district 18 of Tehran and the sample size was determined using Morgan table. After survey from teachers, data analysis. The results with using One Sample T-Test indicated that the teaching methods of this book were in the medium to high, in terms of contexts, inputs, processes, and outputs. Also, the results of Friedman test show that the most important priority of teaching methods of this book was the contextual factors, and the least important factor is the inputs.

Keywords: Curriculum, Media Literacy, Teaching, Thinking, Media Literacy Training.

\section{Introduction}

One of the necessities of globalization is the need for an education with media training to prepare learners in order to meet the challenges of life that are changing and unpredictable (Myers, 2007). The variety of communication technologies has made it easy for people to communicate with anyone in anywhere on the globe at any time. So, they are a very powerful and useful tool that utilizes advanced technologies to transfer information effectively around the world. Children and adolescents have experienced significant changes in their lifestyle in recent years. One of the most important changes is the emergence of new media that are much more influential than their predecessors due to their specific characteristics such as cheapness, availability and interactivity (Ameli, 2011). In today's global village, anyone with a mobile phone or personal computer (PC) can easily access up-to-date and global information in any field of human knowledge in less than a few seconds. Today's information is not difficult to access; but, Are we able to process and understand all media messages? Do we have enough time for this? Can thinking and media literacy training, as an appropriate solution, teach person skills to be active in the media and to choose from the vast amount of information available to him or her every day? The goal of media literacy is to promote critical understanding and active participation. Media literacy, however, is an educational approach in 21 st century, shapes an understanding of the role of media in society and considers the acquisition of essential research and expression skills that necessary for citizens in the age of globalization (Sheram \& Durkin, 1998).

Media literacy is a set of skills that one can rely on to clearly understand what he/she receives from different media; identify needed information, select and evaluate more valuable and accurate information and ultimately exploit it (Hafezi \& Bakhtiyari, 2004). Also, teaching media literacy in the community is a mix of effective media production techniques and insights to identify which of these media tools can provide useful and essential information to public opinion in today's media age (Sharbatiyan \& Eskandari, 2015). Media literacy seeks to identify the relationship between knowledge and power, and between power and social justice. Media 
literacy is the power to understand and make meaning in the media (Shokrkhah, 2019). Media literacy is a component of the mental ability that motivates one to make decisions and to act wisely, and includes values such as truth, justice, self-determination, and personal criticism (Eidizadeh, 2013; Hesami, \& Rad, 2019).

The field of media literacy education has emerged in the world for the last 40 years and the importance of education and the broad concept of "literacy" has expanded over the years. Media literacy education has been formally introduced by the Canadian educational system. Media literacy is currently taught as a lesson in many countries such as the United Kingdom, Australia, South Africa, Canada, United States and Japan, and simultaneously is developing in New Zealand, Italy, Greece, Austria, Sweden, Denmark and Switzerland (Kress, 2003). New age, as a fast era of communication, has been accompanied with very simple and fast entry, minimum access restrictions, communication with the world in various forms, lack of time and space constraints, access to various databases and participation in economic-scientific-culturalart activities. Its speed and flexibility have led to fundamental changes in the pillars of society, as familiarity with other societies, willing or unwanted, brings new norms to the extent that norms and values of the community are diminished in that range.

Among the strategies that can be taken to tackle such challenges are social surveillance, enjoining good and forbidding wrong as well as compilation of up-to-date and comprehensive textbooks such as media thinking and literacy are as a form of social control by each individual for preservation of the values and norms of the religious community (KeshtyAray \& Akbarian, 2010; Soleimani, \& Esfahani, 2018). The expansion of cyberspace in the field of parent-child relationships has also brought about changes, such as decreasing role of families as a reference, decreasing relationship between parents and children, the generation gap due to technological development, loss of privacy between children and parents. Due to the importance of cyberspace in the development of societies in our society, in recent years, much attention has been paid to information and communication technology (Sadeghian, 2005). It should be noted that various factors such as content of curriculum, use educational technology in classroom, teacher motivation, socio-educational and cultural factors, student participation in group discussions of media thinking and literacy lesson, classroom management evaluation, teaching methods, and extra activities are important in teaching this lesson. To be successful in the $21 \mathrm{st}$ century, teachers must train students to be lifelong learners, and this can only happen when the process of pure transition-based learning is changed.

In the meantime, teachers need to keep pace with current developments and be fully familiar with information and communication technologies that affect student learning and academic development, and can train people with information literacy to be innovative and creative thinking. Nowadays, traditional or passive teaching-learning methods do not meet the needs of learners and students, especially in teaching media thinking and literacy lessons. 
Because using passive methods to achieve problem-solving skills, collaboration are not possible. As a result, the student does not understand the pleasure of science and so school is boring and unpleasant for them. One of the solutions to such problems is to implement new and effective ways of training and teaching.

Research about teaching is one of the most important issues that provides appropriate feedback for analyzing educational issues, fundamental decision making and strategic planning for educational authorities and stakeholders in one hand; and on the other hand, teachers try to improve the teaching methods and thus increase the quality of teaching by being aware of the quality of their performance during teaching (Shabani-Varaki \& Hosein-Golizadeh, 2006). The teaching profession is undoubtedly one of the most difficult jobs in the current era, because in addition to a full awareness of knowledge and proficiency, each teacher must have the art and experience of teaching. In many countries, teachers need to have a valid and scientifically certificate based on successfully pass a teaching course in teaching field, and then they should improve their scientific and practical capability through continuous In-service training courses (Fathi-Vajaragah, 2008).

The new textbook, "thinking and media literacy", is developed by the Textbook Compilation Bureau and distributed for teaching in 10th level of secondary school. In the first step, the action is very important and necessary, but the issue is the content of textbook that should be included in each student's mind. Also, the gap between researches in this area, including lack of comprehensiveness and some sporadic writing has caused many considerations to be neglected. Media thinking and literacy lesson should be taught by those who are dealing with media, have skill in this field, are familiar with a variety of effective teaching methods, and have the necessary facilities for topics of each chapter of the book. Therefore, in this study, the research questions are:

1. What methods are effective in teachers' viewpoint to teach media thinking and literacy lesson?

2. How much relation is there between contents of this book "thinking and media literacy" with the previous teachers' learning?

3. How much relation is there between content of this book "media and thinking literacy" with predicted educational purpose?

4. What are the practical solutions in teachers' perspective in the classroom?

\section{Research method}

The type of research in this study is descriptive-analytical as well as survey. The statistical population of the study consisted of all teachers in 10th level of secondary school in district 18 of Tehran who have taught this lesson in the academic year 2018-2019 and in sampling used Morgan table ( $\mathrm{S}=1208, \mathrm{~N}=291)$. First, a list of all teachers was prepared and then 
291 teachers were selected by simple random sampling. The research tool was researcher-made questionnaire. This questionnaire was prepared based on the views of experts in Teaching in Media Thinking and Literacy Lesson, which initially had 21 questions, which were reduced to 10 questions after expertise and multiple expert reviews. The validity and reliability of this questionnaire were evaluated by Cronbach's alpha test and its reliability was confirmed (0.79). Data were analyzed with using SPSS software version 22. Data analysis consisted of two main sections: description of data (central and dispersion indices) and data analysis (one-sample ttest and Friedman test).

\section{Findings}

To answer the first question, first investigate the research findings regarding the degree of achievement of the desired goals based on the one-sample t-test. Then, the compatibility of the media thinking and literacy lesson goals were investigated with the researchers conducted inside and out of the country. The goals identified for teaching methods and contexts, and the extent to which these goals have been achieved are as follows:

1. The first goal of the teaching methods of the new compilation book "media thinking and literacy" according to the circular sent to the schools by the Department of Education is to prefer the teaching method that offers opportunities for students to repeat and reconstruct the contents learned $(t=49.626)$.

2. The second goal of the teaching methods of this book, according to the circular, is to emphasize on the practical activities of the students $(t=44.299)$.

3. The third goal of the teaching methods of the book "media thinking and literacy" according to the circular issued by the education is to identify and prioritize appropriate teaching methods to the needs of the students (lectures, expository, etc.) $(\mathrm{t}=48 / 874)$.

4. The fourth goal of the teaching methods of this book is methods that lead to meaningful learning $(t=59.519)$.

5. The fifth goal of the teaching methods of the book "media thinking and literacy" is to provide an opportunity to express views and opinions $(t=46.554)$.

6. The sixth goal of teaching methods of this book is to focus on the power of students' analysis $(t=51.343)$.

7. The seventh goal of the teaching methods of the new book compilation book "media thinking and literacy" is to: distinction and comparing power of information, issues and situations from each other $(\mathrm{t}=49.329)$.

8. The eighth goal of teaching methods of this book is to measure students' prior information before starting the lesson $(t=39.772)$. 
9. The ninth goal of the teaching methods of this book is to fit the events of real life environment $(\mathrm{t}=44.185)$.

10. The tenth goal of teaching methods of the book is to provide positive and negative examples of subject and student comparative power $(\mathrm{t}=38.200)$.

Among the questions raised, question 10 refers to Innovative teaching method. The main purpose of this method is to innovate, breaking the barrier of traditional rules and creating new ways for solving problems through comparison. This is a way to help people break old previous mindsets and find the right way to think in a new way to the subject. On the other hand, goal 4 shows that teachers are most likely to create meaningful learning to make connections between new and previous learned content. The most important thing that affects learning is the learner's previous knowledge; so, identify them and then start teaching. Therefore, in the questionnaire for the teaching methods of this book according to the one-sample t-test, the least achievement of the goals realization is related to question 10 of the questionnaire means to provide a positive and negative sample of the subject and the student's comparison power $(t=38 / 200)$, and the highest degree of realization is related to question 4, namely applying the methods that lead to meaningful learning $(t=59.519)$.

In the present study, according to the survey questionnaire from teachers, the results of the table show that there is a significant difference between the sample mean and the hypothetical mean of the community at the significance level of $0.01(\mathrm{t}=63.10)$. The results indicate that the teaching methods of this book are above average in terms of teaching contexts.

To answer the second question, some cases of the teaching methods of this book in terms of teaching inputs in a circular sent by the Ministry of Education were specified in questionnaire 10 to 20 that their achievement on the basis of the one-sample t-test is as follows:

11. Influence of in-service courses on increasing empowerment $(t=23.529)$.

12. Interaction and cooperation of the school executive $(t=33.213)$.

13. Use of various educational resources and educational aid related to the lesson $(t=$ 39.116).

14. Using several teaching methods $(t=37.986)$.

15. Not knowing enough the book as a source of information $(t=35.779)$.

16. Providing new exercises and contents for not being stagnant of the class $(\mathrm{t}=52.335)$.

17. Participation of all class members in-group activity $(t=49.925)$.

18. Providing classroom space for criticism, questioning, challenge, talking about argument, challenging the subject matter $(\mathrm{t}=46.865)$.

19. Generating new thinking using problem solving method by comparison $(\mathrm{t}=46.528)$.

20. Full overlook on specialized subject matters $(t=43.947)$. 
Among the questions asked in the survey questionnaire, the least realization of process design is related to question 11 means in-service courses on increasing empowerment $(\mathrm{t}=$ 23.529), and the most realization is related to 16 question means providing new practice and contents for not being stagnant of the class $(t=52.335)$.

According to statistics, while in-service education of the teachers is one of the most basic educational needs of any society, in-service training of this lesson has not been fully effective in achieving predetermined goals. The least reason for this is inconsistency of educational content of courses with needs of teachers as well as quality of holding. Whereas one of the ways to empower in-service teachers is to introduce them to new teaching methods; disregarding "in-service training" for updating and empowering teachers will eventually lead to have teachers, who have neither up-to-date information nor valuable skills, while a capable teacher can qualify the education process and ultimately educate a generation that is the source of the work for the country. Therefore, in question 16, teachers use from providing exercises in the form of classroom questioning and activities, making new topics, and student research to ensure that the classroom is not stagnant.

According to the teachers' survey questionnaire, the results show that there is a significant difference between the sample mean and the hypothetical average at the significant level of $0.01(t=63.10)$ on the realization level of the outputs of the teaching methods of the new compilation book, namely "media thinking and literacy". The results indicate that the teaching methods of new compilation book "media thinking and literacy" are in medium to high status in terms of teaching inputs.

In response to the third question, the educational goals outlined in the circular include the role of teachers, schools and education area. The teacher is one of the important elements in the curriculum that has a facilitating role. One of the key qualifications of a teacher is to be familiar completely with the basic concepts, principles and rules of science. If this qualification is weak, there will be a slowdown in his/her educational role. The main condition for the success of the teaching method of this book is to first become known to the teacher and to be fully familiar with the educational goals and mission of the book. Questionnaires about the relationship between the content of the book and the educational goals are from question 20 to 30 that their realization rate is based on one-sample t-test:

21. Using predictive methods in the book for evaluating different dimensions $(t=$ 49.912).

22. Implementation of the teaching process and classroom activities in accordance with the predicted goals and plan $(\mathrm{t}=50.419)$.

23. Use of predicted educational tools and technology $(\mathrm{t}=41.271)$.

24. Providing teaching according to the schedule $(\mathrm{t}=49.818)$. 
25. Identifying weaknesses, deficiencies, and inadequacies of teaching $(\mathrm{t}=56.343)$.

26. Facilitating learning and empowering poor students in terms of verbal ability $(t=$ $58.585)$.

27. Developing the thinking that the students solve the problem themselves $(t=47.428)$.

28. Not providing the content directly to the learners, as well as asking regular questions to guide students' subjective activities to the subject matter $(\mathrm{t}=43.756)$.

29. Inviting experts on the subject of the book (expert of media, cyberspace, etc.) $(t=$ 26.139).

30. Attempts and emphasis on group activity more than individual activity $(\mathrm{t}=37.624)$.

According to the one-sample t-test is related to questions of the processes, the least realization of process is related to question 29 means to invite experts on the subject of the book (expert of media, cyberspace, etc.) $(\mathrm{t}=26.139)$; and the most realization of processes is associated with question 26, namely facilitating learning and empowering poor students in terms of verbal ability $(\mathrm{t}=58.585)$.

According to the above statistics, it appears that there is no context and conditions for inviting out-of-school media professionals as a guest to explain some of the information regarding media thinking and literacy lesson. Among the benefits that this can have are: 1) the importance of the lesson, 2) the attractiveness of the lesson and its rapid learning.

On the other hand, most of the votes are focused on reinforcing the student's vocabulary; surely shy students are in a secluded in the classroom, who refuse to make contact with individuals and participate in social activities. So they need to be seen, and provided, by the teacher, such as role-playing, entering small groups for collaborative learning, expressing their views and opinions, and being self-sufficient.

According to the survey of teachers, the results indicated that there is a significant difference between the sample mean and the hypothetical average of the community at the significant level of 0.01 , regarding the status of teaching processes $(t=66.31)$. The results show that the methods of teaching "media thinking and literacy" lesson are in medium to high status in terms of teaching processes.

To answer the fourth question, which are some of the practical solutions to the teaching methods of the book "media thinking and literacy" in the teacher survey questionnaire is from question 30 to 40 , that their realization rate based on the one-sample t-test is:

31. Determining the success rate and failure of the selective teaching method by receiving feedback from students through appropriate tools $(\mathrm{t}=50.883)$.

32. Making a question from booklet and textbook about evaluation $(t=43.112)$.

33. Evaluation according to student problem solving ability $(\mathrm{t}=43.588)$. 
34. Evaluation with regard to cooperation, participation and respect for others' opinions $(\mathrm{t}=46.928)$.

35. Evaluation of students considering their ability and knowledge to deal with specific subjective and objective situations $(\mathrm{t}=42.612)$.

36. Evaluation with regard to creating motivation in students and knowing value of their thinking and knowledge $(\mathrm{t}=51.520)$.

37. Using question and answer to recall past material $(t=53.334)$.

38. Making questions for students $(t=23.646)$.

39. Assessment of student learning (self-assessment) by asking these questions in this lesson $(\mathrm{t}=32.913)$.

40. Evaluation according to the level of student understanding (analysis and criticism) of the course materials as well as the practical work (in the form of media, articles, projects, etc. $)(\mathrm{t}=39.017)$.

According to the one-sample t-test is related to questions of practical solutions for presenting the lesson in the class (output), the lowest realization is related to question 38, i.e., Making questions by students $(\mathrm{t}=23.646)$ and the most realization is associated with question 37 , namely, the use of question and answer to recall past material $(\mathrm{t}=53.334)$.

According to the above statistics, it can be said that teachers use the question-andanswer method to attract the student's attention to a new lesson or matter and to teach it. Also, they do not directly address the matter, but by asking regular questions drive the students' mental activity into new content and guides them to discover new concepts themselves. At the same time, it should be noted that the questions should be designed according to the students' scientific backgrounds and raised in a way that attract their attention. In contrast, question 38 indicates that teachers have a question-and-answer attitude and have not provided problemcentered situations where the student is a spontaneous, designer and analyst of the question and not dependent on the asking the question from the teacher.

The investigations of the questionnaire indicate that, regarding status of teaching outputs, there is a significant difference between the sample mean and the hypothetical mean of the population at the significance level of $0.01(\mathrm{t}=62.17)$. The results show that the method of teaching this book in terms of outputs is in medium to high status.

\section{Discussion}

Today, in addition to training citizenship for a society, the need to preparation of citizens for life in the international community has become an educational necessity. Teaching media literacy to citizens in the age of globalization is a total concept that relies on media, cultural, social, historical, political, and technological studies and it can be applied to teaching better 
ways of living in the age of information and communication in particular in one society and in the global community in general. Media literacy is a tool for protecting citizens against the negative effects of the mass media. The subject of media thinking and literacy, like any other educational subject, is wide-ranging. Obviously, training such a volume of knowledge, skills, and attitudes is not possible for a lesson with two hours teaching per week in a school year. In other words, media literacy is one of the most important topics in modern societies. The pattern of proper use of media and having media literacy in human societies are among important foundations of the economic and social development of any society. One of the important foundations is the creation of low-level media literacy, especially in the educational system of each country. Because in educational system, students will learn to practice the critical thinking that underlies democracy and any kind of economic and social development in any country.

In the present study, due to the importance of teacher role in implementation of this lesson, the teachers themselves were surveyed. According to the findings of this study, based on the teachers' survey questionnaire, the highest number of respondents was related to female; the highest employment status was official; and the largest percentage of respondents reported their history between 21-25 years. Taking into account the age and high history of the teachers participating in the survey, and according to results of the survey as well as statements of teachers at the end of the questionnaire (based on the teaching method of this lesson should be executed in the form of media space according to the conditions and requirements, a handbook and $\mathrm{CD}$ be with teachers, to be taught in low-population classrooms, not to be considered as an excessive lesson by officials and executives), because of get accustomed of teachers with traditional and passive teaching conditions, unwillingness to change the ways of work, their inability to specialize in new situation, and their inability to re-learn, the inability to learn, and the effort to maintain status, past and present traditions and methods; can be found in their resistance to implement the effective teaching method of "media thinking and literacy". While it is clear that, this lesson is the basis for a conscious and evolving society in the future.

Similar results found Ballesta-Pagán, Martínez-Buendía, \& Céspedes-Ventura (2007), regarding teachers' assessment of the digital teaching materials created point to the validity and suitability of the matrices used, both at the pedagogical and the technological level. The above makes us think that leads to pose as a challenge the linking of information technologies and the communication in the Latin American university environment. It would be desirable to deepen the studies in teaching proposals to increase the presence of the media in the teacher training. This implies an approach to the analysis of the activity carried out by its teachers and contribution to student training, developing appropriate strategies that allow emancipatory training (Saez \& di Nápoli, 2019).

The results of media thinking are compared with that found by Uriarte-Álvarez, (2011) where media literacy as a tool to train competent children, critics and literates in media. scope 
was the application and development of an educational strategy for media literacy, as well as the possibility of developing critical thinking skills for educational strategies. Another scope was to be able to adapt the educational strategy to the curriculum, which shows that media literacy is a tool that can be incorporated into the curriculum of that institution. The aforementioned makes us reflect on the growth of the influence of the information and communication media, as well as the tools intended for the media training of society, it is gaining great relevance day by day and a greater presence in the educational sphere of individuals. However, their presence is greater does not imply that the subjects are clear about what we talk about when we do media education, why we do it or what it means to do it (Marín \& Cabero, 2010).

\section{Conclusion}

Based on the findings, it can be concluded that how media is used depends largely on the quality of media literacy of individuals. Therefore, it is better to provide the necessary background for the development of media literacy in the educational system. The use of the media has been mixed with everyday life in many ways. This is especially true for television, which is always associated with family life. The media can change the realms of life with their presence in everyday life. Media converts private domains into public, and public into private. Media literacy is like a diet that intelligently takes care of what is right and what is harmful; what to use and what not to use; or on what basis each substance should be consumed. Media literacy can teach media audiences to break out of passivity and consumption and enter into an interactive and proactive equation that ultimately benefits them. In other words, media literacy helps us to use the media in a smart and useful way. Therefore, all of these require conditions that can emerge in the light of good and effective teaching.

Nowadays, less attention is paid to teaching and teaching methods in the country and uniformity and overuse of teaching method slows down the teaching method. Teaching is integration of both science and art; and the teacher must have both of them. Teaching is not the only relationship between teacher and student to transfer their knowledge. Teaching encompasses a variety of concepts, such as attitudes, beliefs, habits and behavioral styles, and in general the types of interpretations that we want to make in students, and each of the above areas has different characteristics. Teaching should be a regular, purposeful activity and be preplanned. Its aim should be to create favorable learning conditions and to influence the teacher and student. The important point in the teaching process is teacher determines of what needs to be learned in order to provide educational content and appropriate activities to the lesson and understanding of the students. 


\section{References}

Ameli, S. R. (2011). A bipartisan approach to cyberbullying damages, crimes, laws and policies. Tehran: Amir Kabir.

Ballesta-Pagán, J., Martínez-Buendía, J., \& Céspedes-Ventura, R. (2017). Un modelo integrador para la alfabetización mediática y la competencia digital en Educación Primaria. Revista Fuentes, 19(2), 139-154.

Eidizadeh, T. (2013). Media literacy and choice of computer games. Journal of Social Science Month Book. 69, 83-88.

Fathi-Vajargah, K. (2008). Effective teaching techniques. Tehran: Ayeezh.

Hafezi, E., \& Bakhtiyari, Z. (2004). The Role of Patient Information Literacy in Utilizing Library Resources in Astan Quds Razavi Central Library. User education and development of information literacy in libraries and information centers. Mashhad: Organization of Libraries, Museums and Documentation Center of Astan Quds Razavi.

Hesami, M., \& Rad, S. S. (2019). The relationship between knowledge management and employee education knowledge in Power Distribution Company of Golestan province. Journal of management and accounting studies, 7(02), 39-43.

KeshtyAray, N., \& Akbariyan, A. (2010). The virtual age and the challenges ahead. The first international responsible citizen conference.

Kress, G. (2003). Literacy in the New Media Age. New York: Routledge.

Marín, V., \& Cabero, J. (2010). Educación mediática y dimensiones educativas de las TIC. Córdoba: Servicio de Publicaciones de la Universidad de Córdoba.

Myers, C. (2007). Critical Thinking Training. Tehran: Samt.

Sadeghiyan, E.(2005). The Impact of the Internet on Children and Adolescents. Nama electronic magazine. No. 4.

Saez, V., \& di Nápoli, P. N. (2019). Educación mediática en la formación docente de la universidad: un espacio para el pensamiento crítico. In XIII Jornadas de Sociología. Facultad de Ciencias Sociales, Universidad de Buenos Aires.

Shabani Varki, B., \& Hossein Golizadeh, R. (2006). Investigating the quality of teaching in university. Journal of Research and Planning in Higher Education. 1(12), 1-22.

Sharbatiyan, M. H., \& Eskandari, Z. (2015). Sociological Analysis of Cultural Capital Persons and their Factors. Khorasan Cultural-Social Study Quarterly. 2(10), 57-84.

Sheram, V. \& Durkin, Ku. (1998). TV in our children's lives. Tehran: Center for Research, Studies and Programming of the Islamic Republic of Iran Broadcasting.

Soleimani, M., \& Esfahani, M. K. (2018). The impact of network of social relationships effective in drug addiction and crime in connection with the it. Journal of Social Sciences and Humanities Research, 6(04), 1-5.

Shokrkhah, Y. (2019). What is Media Literacy? Teaching Media Literacy in Iranian Schools. 
Hamshahri Online. Retrieval on October 29, 2019. Codex, 385694.

Uriarte Álvarez, M. R. (2011). La alfabetización mediática como herramienta para formar niños competentes, críticos y alfabetas en medios (Master's thesis, Universidad Iberoamericana Ciudad de México. Departamento de Comunicación). 